\title{
FACTORS INFLUENCING TECHNOLOGY ADOPTION BY TRADITIONAL AFRICAN VEGETABLE FARMERS IN NORTHERN GHANA
}

\author{
Issaka $^{1 *}$, Y. B., Nyarko², G., Quaidoo' ${ }^{1}$ D. \\ ${ }^{1}$ Department of Agribusiness Management and Finance, Faculty of Agribusiness and Communication Sciences, University for \\ Development Studies, Tamale, Ghana. \\ ${ }^{2}$ Department of Horticulture, Faculty of Agriculture, University for Development Studies, Tamale, Ghana. \\ *Corresponding Author: yakubu_issaka@uds.edu.gh
}

\begin{abstract}
The production of traditional African vegetables is an age-old tradition among the people of the northern region of Ghana. However, the knowledge base of traditional African vegetable production remains local due to a lack of research and policy support. Therefore, the adoption of improved technology among traditional vegetable farmers is generally low and impedes efforts to promote widespread cultivation, consumption and even commercialisation. This study aims at clarifying potential factors that determine the adoption of technologies by traditional African vegetable farmers in the northern region of Ghana. One hundred and five (105) respondents in five communities and across two administrative districts in the northern region were selected for an in-depth survey using a combination of quantitative and qualitative data collection methods. In addition, a logit regression was used to determine the effect of various factors on technology adoption by farmers. Among the factors, the educational level of a farmer, access to credit, farm size, experience in farming and access to extension support were found to be important factors affecting the decision of traditional African vegetable farmers to adopt improved technology. The results of this study can help enhance the effectiveness of policy re-orientation towards a more effective commercialisation of traditional African vegetables in Ghana and elsewhere.
\end{abstract}

Keywords: Traditional African vegetable, farmers; Ghana, rural, technology

\section{Introduction}

The production and consumption of vegetables by households is a common practice in Africa. Vegetables are usually cultivated on a subsistence scale in rural and peri-urban areas under intensive gardening systems, gathered from the wild or integrated into cereal-based rain-fed farming systems (Ngugi et al., 2006). Among these is a vast collection of indigenous African vegetables (IAVs) which are the mainstay of traditional diets, especially in rural Sub-Saharan Africa (Muyonga et al., 2017). Indigenous vegetables refer to a category of plant species whose leaves, fruits or roots are acceptable and used as vegetables over a long time by rural and urban communities through custom, habit and tradition (Muhanji et al., 2011). According to Abukutsa-Onyango (2010), it is common to refer to indigenous or introduced vegetables that have become part of the culture of a people as traditional due to prolonged use. Thus, the term traditional African vegetables (TAVs) and AIVs are often used interchangeably. The African continent serves as a home to many indigenous vegetable species, most unexploited. According to the Plant Resources of Tropical Africa (2004), only $21 \%$ of the 30,000 plant species found in tropical Africa is utilised by man, of which traditional vegetables constitute about 
6.2\%. Species endemism has been estimated to be about $45 \%$ for tropical Africa indicating that a large number of the species found in tropical Africa, including indigenous vegetable species, are not found elsewhere in the world ( Muhanji et al., 2011; Kiambi \& Atta-Krah, 2003; Adebooye \& Opabode, 2004).

Northern Ghana is endowed with many beneficial indigenous vegetables as vegetable production constitutes an essential and integral part of cerealbased farming systems. A study of cereal-based vegetable production systems in northern Ghana by Issaka et al. (2016) revealed that every household cultivates at least three different types of vegetables, either sole cropped or intercropped with other field crops. Common traditional African vegetables found in northern Ghana include African eggplant (Solanum ethiopicum), okra (Abelmoschus esculentus), jute mallow (Corchorus olitorius), amaranth (Amarantus sp.), kenaf (Hibiscus cannabinus), Roselle (Hibiscus sabdariffa), bitter leaf (Vernonia amygdalina), cowpea (Vigna unguiculata), pumpkin (Cucurbit sp.) and Cassava (Manihot esculanta).

Despite its acclaimed contribution to food security, existing policy to promote the commercialisation of TAVs in Ghana and elsewhere in Africa is insufficient (Abukutsac-Onyango, 2010; Agency for Health and Food Security, 2020). Thus, the knowledge base for the cultivation of TAVs remains traditional and is largely undocumented (Vorster et al., 2007), making the need to improve the availability of reliable scientific information critical for promoting the cultivation and utilisation of these vegetables (Afari-Sefa et al., 2012). A compelling need for the commercialisation of TAVs is supported by the fact that they have significant health, ecological, agronomic and cultural values. Firstly, TAVs play an essential role in alleviating hunger, malnutrition and food insecurity (Afari-Sefa et al., 2012). It is common knowledge in northern Ghana that rural populations usually depend on TAVs in times of hunger. Indeed Chagomoka et al. (2015) found that rural communities around Tamale in the northern region of Ghana consume more vegetables than their peri-urban and urban counterparts. Secondly, the high nutritional value of TAVs confer on them an essential role in the elimination of nutrients deficiencies in the diet of children and pregnant women (Uusiku et al., 2010). Thirdly, TAVs are pro-poor crops: they require low capital investments and are easily accessible to the poor. As such, they are essential for household food security and also have a high potential to contribute to household cash security among the poor (Faber et al., 2010). In Northern Ghana, the cultivation of traditional vegetables is a significant incomegenerating activity for women who often have limited access to suitable land to cultivate other crops (Chagomoka et al., 2015). Moreover, urbanisation has increased the cultivation of vegetables, increasing income opportunities for the vegetable growers (Nchanji, 2017; Amoah et al., 2014). Lastly, TAVs are better adapted to harsh climatic conditions and are short duration crops (Abukutsa-Onyango, 2010). With usually shorter growing cycles than staple crops, TAVs can be less affected by environmental threats such as drought. In general, they require less space than staple crops and can maximise natural resources when water and nutrients are scarce (Tenkouano, 2011). This makes them suitable for Northern Ghana as the area continues to experience shorter and unreliable rainfall patterns under rapidly changing and unpredictable climatic conditions.

Although Ghana can meet local demand for vegetables, current production is seasonal and yields comparatively low compared to neighbouring countries (van Asselt et al., 2018). Several constraints have been identified along the vegetable value chain in this regard. These include poor husbandry techniques, inadequate access to seed, a poor extension service, insufficient use of fertilisers, unreliable rainfall, inadequate irrigation facilities, a lack of organised vegetable processing and marketing and the low income derived from vegetables during the regular growing seasons (Sinnadurai,1973). To address some of the constraints, the World Vegetable Center (AVRDC), in collaboration with its partners in Ghana, the 
University for Development Studies (UDS) and the Savannah Agricultural Research Institute (SARI), developed and disseminated several technologies on TAVs to farmers in Northern Ghana between 2013 and 2016. Technologies introduced include 24 improved varieties of okra, amaranth, jute mallow and roselle; drip irrigation and pedal pump. The intervention aimed to increase the production and utilisation of TAVs by addressing specific constraints to their effective commercial production in northern Ghana. This was against the background that TAV value chains in northern Ghana are poorly developed and are characterised by conditions such as low productivity, poor quality planting material, limited knowledge of post-harvest management and a lack of awareness of the nutritional benefits these vegetables can provide. Of particular interest is the lack of application of improved vegetable production technologies by farmers. Consequently, this study aims to determine the factors that influence the adoption of improved technologies by TAV farmers in northern Ghana.

\section{Methodology}

\section{The Study Area}

The study was conducted in the Savelugu/Nanton and Tolon districts in the Northern region of Ghana. Both districts fall within the Guinea Savannah ecological zone. The area records one rainy season from April/May to September/October followed by a prolonged dry season, from November to March, during which most water bodies usually dry up. These districts are primarily rural, and agriculture is the primary source of livelihood for the people. The Savelugu/Nanton district is located $16 \mathrm{~km}$ to the North of Tamale, the regional capital. The district shares boundaries with the West Mamprusi and Mamprugu/Moaduri districts to the north, the Karaga district to the East, the Tolon district to the west, the Tamale Metropolis to the south and the Yendi Municipality to the South-East. The altitude of the district ranges between $122 \mathrm{~m}$ and $244 \mathrm{~m}$ above sea level and has a population density estimated at 68.9 persons per sq. $\mathrm{km}$. The Tolon district, on the other hand, is located approximately $25 \mathrm{~km}$ west of the Tamale Metropolis, shares borders with the West Gonja district to the West, the West Mamprusi and the Central Gonja districts to the North and South, respectively and the Tamale Metropolis and Savelugu/Nanton districts to the East. The district's population density is about 65.55 per sq. $\mathrm{km}$ and has an altitude of approximately $156 \mathrm{~m}$. Mean annual rainfall ranges between $950 \mathrm{~mm}-1,200 \mathrm{~mm}$ for both districts.

\section{Sampling and Sample Size}

Five TAVs growing communities in both districts were purposively selected for an in-depth survey. The communities were purposively selected because of the need to include both rain-fed and irrigated vegetable production. This was necessary as it allowed researchers to include vegetable production in both the dry and rainy seasons. Therefore, access to irrigation, which enabled vegetable production throughout the year, served as the primary criterion for inclusion. A total of 105 respondents were randomly selected; twenty-one (21) in each of the five communities. Within each community, simple random sampling was employed to select individual TAV farmers for interview.

\section{Types of Data and Data Collection Methods}

The main source of data for the study were primary data. Primary data were complemented with secondary data obtained from the Ministry of Food and Agriculture, the Savannah Agricultural Research Institute and the University for Development Studies. Secondary data included the types of technology used by vegetable farmers and the types and extent of various vegetables cultivated. A mixed-method approach, consisting of qualitative and quantitative data collection methods, were employed during the study. This allowed for triangulation and improved data quality. Individual and key informant interviews of the Ministry of Food and Agriculture staff in both districts were conducted to obtain preliminary information. This was followed by detailed information gathering through focus group discussions, field observations 
and household interviews. Questionnaires targeted at households were administered to farmers to obtain quantitative data. One focus group discussion was conducted within each community with TAV farmers. The participants in the focus group discussion were selected based on current engagement in TAV production. The research team also visited selected farms and interacted directly with farmers. This enabled the research team to observe production practices and other field operations, notably, cropping patterns, cultural practices, and inputs used.

\section{Methods of Data Analysis}

The data collected were analysed in two phases. Firstly, descriptive statistics were employed to describe and present the socio-economic characteristics of respondents and related attributes of traditional vegetable cultivation. Secondly, the Logit regression model was used to analyse the determinants of technology adoption among farmers.

\section{Variables and a priori expectations}

Table 1: Description of variables and a priori expectations

\begin{tabular}{|c|c|c|c|c|}
\hline $\begin{array}{l}\text { Independent } \\
\text { Variable }\end{array}$ & $\begin{array}{l}\text { Slope } \\
\text { coefficient }\end{array}$ & Description & Measurement & $\begin{array}{l}\text { A priori } \\
\text { expectatio } \\
\text { n }\end{array}$ \\
\hline $\mathrm{X}_{1}$ & $\beta_{1}$ & Sex of farmer & $\begin{array}{l}\text { Dummy ( } 1 \text { if a farmer is male and } 0 \text { if } \\
\text { female) }\end{array}$ & + \\
\hline $\mathrm{X}_{2}$ & $\mathrm{~B}_{2}$ & $\begin{array}{l}\text { The educational status of } \\
\text { farmer }\end{array}$ & $\begin{array}{l}\text { Count of number years of formal } \\
\text { education }\end{array}$ & + \\
\hline $\mathrm{X}_{3}$ & $\mathrm{~B}_{3}$ & Access to Credit & $\begin{array}{l}\text { Dummy ( } 1 \text { if farmer has access to credit } \\
\text { and } 0 \text { if otherwise) }\end{array}$ & + \\
\hline $\mathrm{X}_{4}$ & $\mathrm{~B}_{4}$ & Farm size & Acreage & + \\
\hline $\mathrm{X}_{5}$ & $\mathrm{~B}_{5}$ & $\begin{array}{l}\text { Experience in vegetable } \\
\text { cultivation }\end{array}$ & $\begin{array}{l}\text { Count of number of years in vegetable } \\
\text { cultivation }\end{array}$ & - \\
\hline $\mathrm{X}_{6}$ & $\mathrm{~B}_{6}$ & Access to extension & $\begin{array}{l}\text { Number of times extension agent visited } \\
\text { a farmer in the past year }\end{array}$ & + \\
\hline $\mathrm{X}_{7}$ & $\mathrm{~B}_{7}$ & Age of farmer & Years & - \\
\hline $\mathrm{X}_{8}$ & $\mathrm{~B}_{8}$ & Household size & $\begin{array}{l}\text { Count of number of people in the } \\
\text { household }\end{array}$ & $+/-$ \\
\hline $\mathrm{X}_{9}$ & $\mathrm{~B}_{9}$ & FBO membership & $\begin{array}{l}\text { Dummy ( } 1 \text { if farmer belongs to FBO and } \\
0 \text { if otherwise) }\end{array}$ & - \\
\hline $\mathrm{X}_{10}$ & $\mathrm{~B}_{10}$ & $\begin{array}{l}\text { Access to training on } \\
\text { vegetable production }\end{array}$ & $\begin{array}{l}\text { Dummy ( } 1 \text { if received training and } 0 \text { if } \\
\text { otherwise) }\end{array}$ & + \\
\hline $\mathrm{X}_{11}$ & $\mathrm{~B}_{11}$ & Visit a demonstration field & $\begin{array}{l}\text { Dummy ( } 1 \text { if visited a demonstration } \\
\text { field and } 0 \text { if otherwise) }\end{array}$ & + \\
\hline $\mathrm{X}_{12}$ & $\mathrm{~B}_{12}$ & Cost of labour & The total cost of labour in Ghana Cedi & + \\
\hline
\end{tabular}

\section{The Logit Model}

The study adopted the Logistic Regression model to identify the factors that influence the adoption of technology among farmers. The decision to adopt or continue using technology is discrete. Hence, the use of a random utility model, since a farmer $(\mathrm{N})$ faces a choice of adoption or non-adoption among $\mathrm{J}$ alternative actions which will give maximum utility or profit to the farmer. The Logistic Regression model considers $\mathrm{Z}$ as the set of unobserved continuous variables. The larger the $\mathrm{Z}$ value, the greater the probability of adoption of technology. The regression model for the latent variable is stated as follows: 
Where

$$
P_{i}\left(y_{i}=1\right)=\frac{e^{z_{i}}}{1+e^{-z_{i}}}=\frac{1}{1+e^{-z_{i}}}
$$

$\mathrm{P}_{\mathrm{i}}=$ the probability that the $\mathrm{i}^{\text {th }}$ farmer adopts a technology

$e=$ an exponential function

$\mathrm{Z}_{\mathrm{i}}=$ the value of the unobserved continuous variable for the $\mathrm{i}^{\text {th }}$ farmer

From equation 1, the latent variable can be derived as:

$$
Z_{i}=\log \left(\frac{P_{i}}{1-P_{i}}\right)
$$

\section{The Empirical Model}

The variables considered in this study were the sex of a farmer, the educational status of the farmer, size of the farm, visit to a demonstration field, experience in farming, extension contact, household size, membership of Farmer-based Organisation, training received in vegetable production, labour cost and access to credit. The factors that influence the adoption of particular technologies in vegetable production are represented empirically as follows:

$$
Z_{i}=\beta_{0}+\sum_{i-1}^{12} \beta_{n} x_{n, i}+U_{i}
$$

Hence the empirical logit model is specified as:

$$
P_{i}=\frac{1}{1+e^{-\left(\beta_{o}+\beta_{1} x_{i 1}+\beta_{2} x_{i 2}+\cdots \ldots \ldots \ldots \ldots+\beta_{n} x_{i n}\right)}}
$$

This is expressed in the model below:

$Z_{i j}=\beta_{0}+\beta_{1}$ Sex $_{i}+\beta_{2}$ Education $_{i}+\beta_{3}$ Credit $_{i}+\beta_{4}$ Farmsize $_{i}+\beta_{5}$ Experience $_{i}+\beta_{6}$ Extension $_{i}+$ $\beta_{7}$ Age $_{i}+\beta_{8}$ HHSize $_{i}+\beta_{9}$ FBO $_{i}+\beta_{10}$ Training $_{i}+\beta_{11}$ Demo $_{i}+\beta_{12}$ Labour $_{i}+U_{i}$

where the dependent variable $\left(\right.$ Adoption $_{\mathrm{ij}}$ ) represents a farmer $j$ 's tendency to adopt a new technology $i$ and is defined as a farmer's decision to adopt additional technology or not, $\beta_{0}$ is the constant term, the remaining beta values $\left(\beta_{1}-\beta_{12}\right)$ estimate the effects of the corresponding independent variables on the dependent variable (Adoption ${ }_{\mathrm{ij}}$ ) and, $U_{i}$ is the error term representing the unpredicted or unexplained variation in the response variable.

\section{Results}

\section{Demographic characteristics of respondents}

Sex of respondents

Females constitute $71.4 \%$ of all vegetable farmers sampled in the study area. This agrees with other findings that vegetable production is considered a women's job, especially in Africa (Chagomoka et al., 2013). In addition, the study revealed that most vegetable plots belong to men. However, women are allowed to use them for vegetable cultivation during the dry season while men cultivate staples such as 
rice, maize, millet, sorghum, yam and sweet potato on these plots during the rainy season.

\section{Age of respondents}

Vegetable production in the study area is dominated by farmers in their active age of 21 to 40 years. These accounted for $59 \%$ of the sampled respondents, out of which the youth, defined as those within the age range of 21-30 years, accounted for $35.2 \%$. Similar results were reported by Kamga et al. (2013) in their study of vegetable production in Cameroon. Only $10.5 \%$ of respondents were below 20 years of age. This is understandable as the majority of people in this age group fall within the school-going age. About $28.6 \%$ of respondents were between the ages of 41 to 60 years, while $1.9 \%$ of respondents were older than 60 years (Table 2).

Table 2: Demographic characteristics of vegetable Farmers

\begin{tabular}{|c|c|c|}
\hline \multicolumn{3}{|c|}{ Sex } \\
\hline & Frequency & \% Respondents \\
\hline Male & 30 & 28.6 \\
\hline Female & 75 & 71.4 \\
\hline \multicolumn{3}{|c|}{ Age (years) } \\
\hline Below 20 & 11 & 10.5 \\
\hline $21-40$ & 62 & 59.0 \\
\hline $41-60$ & 30 & 28.6 \\
\hline Above 60 & 2 & 1.9 \\
\hline \multicolumn{3}{|c|}{ Marital status } \\
\hline & Frequency & Percentage \\
\hline Married & 80 & 76.2 \\
\hline Single & 25 & 23.8 \\
\hline \multicolumn{3}{|c|}{ Educational background } \\
\hline & Frequency & Percentage \\
\hline Non-Literate & 81.0 & 77.1 \\
\hline Primary to JHS & 6.0 & 5.7 \\
\hline SHS & 18.0 & 17.1 \\
\hline \multicolumn{3}{|c|}{ Farming experience (years) } \\
\hline Minimum & & 1 \\
\hline Maximum & & 41 \\
\hline Average & & 10.7 \\
\hline
\end{tabular}

\section{Marital status of respondents}

About $76.2 \%$ of the sampled vegetable farmers were married, while the rest have never been married, widowed or divorce. Married women have easier access to land as their husbands allow them to use portions of the family landholding. Moreover, married women usually have access to lowlands for vegetable cultivation during the dry season after field crops have been harvested. On the other hand, single women usually do not often have access to family land as priority is given to male household members.

\section{Educational background}

The majority of the farmers $(77.1 \%)$ did not have any form of formal education, $5.7 \%$ have attained primary education, while $17.1 \%$ have completed Senior High School. This situation is not unexpected as available statistics (Ghana Statistical Service, 2010) show that, generally, $55 \%$ of the population living in the northern region have never attended school while $46.4 \%$ have attained education up to the primary level.

\section{Experience in vegetable cultivation}

The average length of experience of a farmer in vegetable production in the study area is 10.7 years. This ranged between 1 and 41 years overall. However, farmers with experience of up to 20 years accounted for $96.2 \%$ of all vegetable farmers. Very few $(3.8 \%)$ have cultivated vegetables for more than 20 years. Thus, it is evident that vegetable farmers in the study area have considerable experience producing traditional African vegetables. This is not surprising since traditional vegetables form an integral part of the farming system in northern Ghana. This is supported by Issaka et al. (2016) in their study of cereal-based vegetable production systems in northern Ghana.

Common leafy vegetables cultivated by farmers in the study area

The common leafy vegetables cultivated in the study area include Amaranthus (Amaranthus hybridus), Corchorus (Corchorus olitorius), Roselle (Hibiscus sabdariffa), Cowpea (Vigna unguiculata), Boabab 
(Adansonia digitata), Kenaf (Hibiscus cannabinus), Bitter leaf (Vernonia amygdalina), Pumpkin (Curcubita sp) and Moringa (Moringa oleifera). The most cultivated leafy vegetables include Amaranthus, Corchorus, Roselle, and Cowpea, which are cultivated by $96.2 \%, 82.9 \%, 74,3 \%$, and $71.4 \%$ of farmers. The rest are cultivated by less than $50 \%$ of farmers (Fig.1)

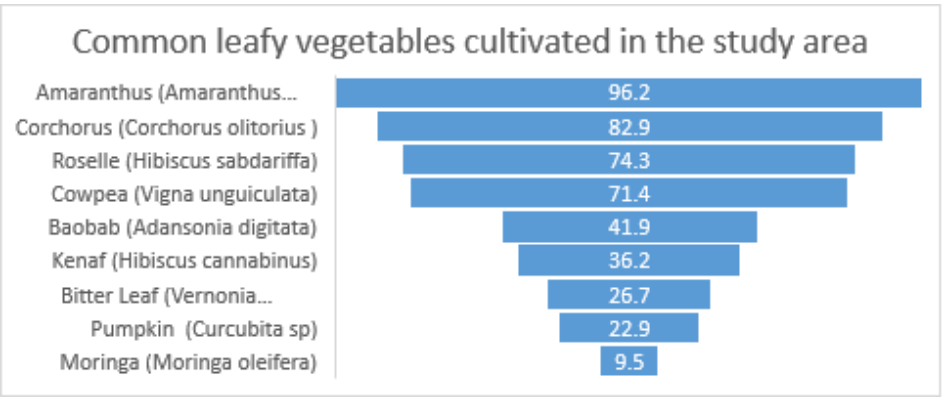

Figure 1: Common vegetables cultivated in the study area

Contribution of traditional leafy vegetables to food and income security

Household decision to cultivate vegetables is informed by the need for food, income or both. Therefore, a wide range of vegetables is cultivated to supply the household's food and cash requirements. An earlier study (Issaka et al., 2016) shows that, indeed, every household in the study area cultivates at least three (3) different types of vegetable, either sole or mixed cropped with vegetables constituting $36 \%$ of all field crops. The majority (45\%) of farmers in the study area cultivate traditional leafy vegetables for revenue and nutrition, while $30 \%$ and $25 \%$ cultivate traditional leafy vegetables for food and income only (Fig 2).

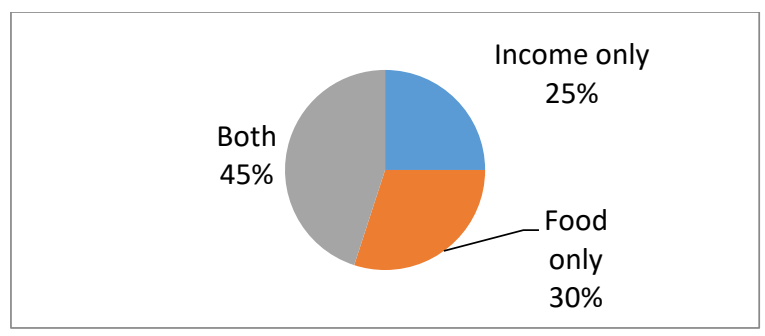

\section{Figure 2: Reasons why households cultivate vegetables}

\section{Food security}

It is important to note that the production and consumption of traditional leafy vegetables are an integral part of the culture of the people in the study area and contributes to food security. It is common for women to cultivate vegetables during the arming season while men concentrate on cereals nd legumes. It is a common practice for women to ntegrate leafy vegetables into the household's oods. Traditionally, indigenous vegetables are used o prepare soups consumed with the local staple ' $\mathrm{TZ}$ ' nd other traditional dishes. About 50\% of touseholds in the study area consume vegetables laily, while $70 \%$ reported consuming vegetables veekly. The vegetables commonly cultivated in the study area are dark-green and nutrient-dense vegetables that are cheaper and accessible sources of micronutrients for these households. Therefore, they have the potential to reduce micronutrient deficiency. This is supported by Chagomoka et al. (2015) in their study on the contribution of vegetable consumption to diets in northern Ghana. In times of scarcity, rural households have tended to rely on traditional vegetables.

\section{Income security}

Urbanisation has provided an opportunity to commercialise traditional vegetables as a rapidly growing urban population in nearby urban and periurban areas offer a growing market for traditional leafy vegetables. Thus, existing irrigation schemes in the study area have become essential sources of leafy vegetables to these urban centres since urban producers cannot meet the growing demand for traditional leafy vegetables. In particular, the production and marketing of traditional leafy vegetables constitute an essential source of income for women in the study area. In some cases, small plots of vegetables are cultivated independently of the household farm holding by women for the sole purpose of supplementing their income. In addition, the traditional leafy vegetable value chain involves women traders who supply vegetables from 
vegetable growing communities to urban areas. The average gross margin per farmer per annum in the vegetable value chain in the study area is about USD123, accounting for $64 \%$ of the gross value.

\section{Technologies employed by indigenous vegetable} farmers

All farmers in the study area have employed one or more of the under-listed technologies at a point in time. However, $95.2 \%$ of farmers were willing to adopt new technologies if only it will increase their income, while the remaining $4.76 \%$ were not interested in adopting new technologies. Irrigation, use of chemical fertilisers and animal dropping are major technologies deployed by traditional vegetable farmers in the study area and are practised by $99 \%, 93.3 \%$ and $77.1 \%$ of farmers, respectively. The rest include mechanical ploughing (35.2\%), grass mulching $(25.7 \%)$, recommended spacing (25.7\%), compost $(12.4 \%)$, use of improved vegetable varieties $(9.5 \%)$, use of organic insecticide (neem extract) $(4.8 \%)$ and plastic mulching $(1.9 \%)$ (Table 3).

Table 3: Common technologies used by vegetable farmers in the study area and their associated constraints

\begin{tabular}{|c|c|c|}
\hline Type of technology & $\%$ Farmers & Associated constraints \\
\hline Irrigation & 99.0 & $\begin{array}{l}\text { - Inadequate knowledge and skill in micro-irrigation } \\
\text { - High cost of equipment }\end{array}$ \\
\hline Chemical fertiliser & 93.3 & High cost \\
\hline Manure & 71.1 & Inadequate access to livestock droppings \\
\hline Mechanical ploughing & 35.2 & $\begin{array}{ll}\text { - } & \text { High cost } \\
\text { - } & \text { Small plots sizes } \\
\end{array}$ \\
\hline Grass mulching & 25.7 & Labour intensive \\
\hline Recommended spacing & 25.7 & $\begin{array}{l}\text { - Inadequate knowledge and skill } \\
\text { - Labour intensive } \\
\end{array}$ \\
\hline Compost & 12.4 & $\begin{array}{l}\text { - Labour intensive } \\
\text { - Inadequate access to raw material }\end{array}$ \\
\hline Improved varieties & 9.5 & $\begin{array}{ll}\text { - Unreliable supply } \\
\text { - } & \text { High cost } \\
\end{array}$ \\
\hline Organic insecticide & 4.8 & $\begin{array}{ll} & \text { High cost } \\
\text { - } & \text { Inadequate knowledge and skill } \\
\end{array}$ \\
\hline Plastic mulching & 1.9 & Inadequate knowledge and skill \\
\hline
\end{tabular}

Additional technologies introduced under the TAV Project

Stakeholders were engaged to identify constraints in the traditional African leafy vegetable value chain in the study area through innovation platforms. Farmer-led demonstration fields were established in selected communities where all the new technologies were demonstrated, with researchers working closely with farmers. As a result, the following technologies were introduced based on specific constraints in the production area:

Drip irrigation: a major concern raised by farmers is the lack of water to irrigate their crops, mainly 
during the dry season. Water is usually scarce during this period and must be used judiciously due to demand for other purposes such as watering livestock and domestic use. Drip irrigation technology was introduced as an affordable and efficient option for vegetable farmers to address this constraint.

Pedal pump: Drudgery was identified as a significant constraint to labour productivity in the vegetable value chain. Vegetable plots are often far from the few available water sources, usually open canals, dug-outs or wells. Therefore, farmers spend several hours drawing water manually to irrigate their crops. To address this constraint, pedal pumps were introduced as an affordable and less labourintensive alternative.

High-yielding crop varieties: low productivity of the available vegetable varieties were identified as a major constraint to farm productivity and profits. Consequently, high yielding varieties of the following crops were identified and disseminated to farmers: 10 varieties of okra, six varieties of roselle, four varieties of chochorus and four varieties of amaranth.

\section{Results of the regression analysis}

A total of 84 copies of the questionnaire were found to be suitable for analysis, the remaining 21 copies of the questionnaire were found unsuitable for analysis due to several errors.

The level of education attained by a farmer, number of extension contacts, access to credit, farm size, visit to a demonstration field, cost of labour and the extent of a farmer's experience in vegetable cultivation were found to exert significant but varying influence on the adoption of technology by vegetable farmers (Table 4).

Table 4: Regression result of factors

\begin{tabular}{|c|c|c|c|}
\hline Variable & Coefficient & Standard Error & $\mathbf{P}>|\mathbf{z}|$ \\
\hline Sex & 0.639896 & 0.7452192 & 0.391 \\
\hline Age & -.0173166 & .0544036 & 0.750 \\
\hline Household size & -.0438335 & .0572119 & 0.444 \\
\hline Educational level & $.5378643 * * *$ & .1912894 & 0.005 \\
\hline FBO membership & -.7524639 & 1.169326 & 0.520 \\
\hline Extension contacts & $1.925436 * * *$ & .7388204 & 0.009 \\
\hline Access to training & -1.433835 & 1.255768 & 0.254 \\
\hline Access to credit & $3.665302 * * *$ & 1.329047 & 0.006 \\
\hline Farm size & $1.531507 *$ & .8478278 & 0.071 \\
\hline Farming experience & $-.2032613 *$ & .1226454 & 0.097 \\
\hline Visit to a demonstration field & $2.40962 *$ & 1.318923 & 0.068 \\
\hline Labour cost & $0.0857606^{*}$ & 0.0421149 & 0.042 \\
\hline Constant & $-6.076658 * * *$ & 2.332604 & 0.009 \\
\hline \multicolumn{4}{|c|}{$\begin{array}{l}\text { Number of Observations }=84 ; \text { LR chi2 }(9)=50.80 ; \text { Prob }>\text { chi } 2=0.0000 ; \text { Pseudo R2 }=0.6003 \\
\text { Log likelihood }=-16.910564 \\
* * *, * *, * \text { indicate significance level at } 1 \%, 5 \% \text { and } 10 \% \text { respectively }\end{array}$} \\
\hline
\end{tabular}

\section{Educational level}

A farmer's educational level affected the decision to adopt improved technology positively and was statistically significant at a $1 \%$ significance level. This means that, as the number of years that a vegetable farmer spends in school increases, it is more likely that the farmer will adopt an improved technology. This meets our a priori expectation and is consistent with other studies in Ghana (Donkoh et al., 2019; Kwarteng et al., 2019; Owusu et al., 2013). 
Furthermore, farmers who have acquired formal education have a better understanding of new technologies since they can obtain additional information about the technologies to enhance their knowledge.

\section{Access to credit}

Access to credit influenced a farmer's decision to adopt improved technology positively and was statistically significant at a $1 \%$ significance level. This result meets our a priori expectation that access to credit has a direct and positive effect on technology adoption. Therefore, farmers who have access to credit are more likely to adopt new technology (Kwarteng et al., 2019; Owusu et al., 2013; Mohammed et al., 2019). This is plausible because some technologies come with additional production costs, such as increased labour and input requirements. Consequently, the ability of farmers to meet these additional costs through the acquisition of a credit is a significant factor in their decision to adopt such improved technologies. For example, in this study, adopting a pedal pump and drip irrigation technologies constituted additional cost.

\section{Farm Size}

Farm size was hypothesised to influence a farmer's decision to adopt a technology positively. True to our expectation, the variable was statistically significant at a $10 \%$ significant level with a positive coefficient. This means that the larger a farmer's total farm holding is, the more likely the farmer would adopt new technology. By implication, farmers with smaller farm holdings are more riskaverse. Although vegetable plot sizes in the study area are generally small, it is usual for farmers to have several vegetable plots in different locations for different crops. This, invariably, spreads a farmer's risk. While findings from other studies (Etwire et al., 2013; Owusu et al., 2013) support the current research, Zakaria et al. (2020) found a negative but significant relationship between farm size and technology adoption by farmers.

\section{Farming Experience}

Farming experience had a negative and significant relationship with a farmer's decision to adopt technology and, therefore, concurred with our a priori expectation. Moreover, it is significant at the $10 \%$ significance level. The result means that, as the level of experience of a farmer increases, the likelihood of adopting a technology rather decreases. This confirms our assumption that as farmers advance in age, they become risk-averse and instead prefer to rely on experience they have acquired over the years rather than experiment with new ideas. On the other hand, other studies (Kwarteng et al., 2019; Zakaria et al., 2020) found a positive influence of farming experience on farmers' tendency to adopt agricultural technology.

\section{Access to extension}

The number of extension contacts positively influenced a farmer's decision to adopt improved technology and was statistically significant at a $1 \%$ significant level. The positive sign of the coefficient is expected since it meets our a priori expectation that, as the frequency of extension contacts with farmers increases, the level of technology adoption also increases. The result is consistent with other findings (Kwarteng et al., 2019; Mohammed et al., 2019; Etwire et al., 2013) but differs from findings by Owusu et al. (2013). It is believed that extension agents increase farmers' awareness of new and improved techniques in farming. Furthermore, adequate accompaniment of farmers by extension officers and other technical experts is critical to technology adoption as their presence reassures and improves farmer confidence in the technologies being introduced. This was amply evident during the 3 -year implementation of the TAV project in the study area.

\section{Visit to a demonstration field}

As expected, visit to a demonstration field was significant and positive at a significance level of $10 \%$. Thus, it meets our a priori expectation that farmers who have the opportunity of seeing new technology, practically, are less averse to adopting that technology. Amfo and Baba (2020) obtained 
similar results from their study on the determinants of technology adoption among vegetable farmers in Ghana. Demonstration of technologies allows farmers the opportunity to assess new technologies before making up their mind whether to accept technology or not. In addition, field demonstrations promote positive adaptive behaviour among farmers as it enables them to interact closely with promoters of technology, thereby clearing any doubts they may have had about a particular technology.

\section{Cost of Labour}

Cost of labour had a positive effect on a farmer's decision to adopt technology as hypothesised and was significant at a $10 \%$ significance level. This implies that as labour costs increase, farmers are inclined to adopt labour-saving technologies to improve efficiency. More efficient technologies mean that farmers can reduce costs. Moreover, as the cost of production increases, as a result of increasing labour costs, farmers will seek opportunities in new technologies that enable them to increase productivity to increase their revenue. This was particularly revealing in the case of higher-yielding improved traditional vegetable varieties introduced to farmers during project implementation.

\section{Discussion}

The cultivation of traditional African vegetables is an important feature of the farming system in the Tolon and Savelugu/Nanton districts of the northern region. Traditional vegetables play a unique role in the customs and traditions of the people in these districts, conferring on them important social, economic and cultural significance. This is consistent with observations made elsewhere in Africa (Adebooye \& Opabode, 2004; Mnzava, 1997). Every household in the study area cultivates two or more traditional vegetables for household consumption and income and is important for household food and income security. As a common practice, women incorporate vegetables into the family farms either as border crops or as intercrop on cereal fields during the rainy season. However, dry season irrigated vegetable cultivation includes an appreciable number of men who control the few valleys and irrigation facilities available during this time. Many men do not cultivate vegetables during the rainy season because it is less profitable as there is usually a glut at this time. Men, therefore, prefer to leave vegetable cultivation to women during this time. It is important to note that apart from farmers who undertake vegetable production on the formal irrigation schemes during the dry season, most farmers in the study area do not have access to technical support. Generally, traditional vegetable farmers do not have adequate access to improved production practices as traditional vegetables are usually less favoured for support by extension service providers. It is interesting, however, to note that vegetable farmers, on their own, have adopted several improved farming practices for the cultivation of traditional vegetables. Some of these practices, such as the increasing use of inorganic pesticides, are disturbing as they pose a danger to consumers' health. As expected, a farmer's educational level, access to credit, farm size, visit to demonstration fields, labour and access to extension influence the adoption of improved technologies by vegetable farmers positively and are important factors in promoting improved technologies among vegetable farmers. Farming experience, however, influenced technology adoption negatively. The positive influence of education on a farmer's adoption of improved technology is consistent with the findings by Uusiku et al. (2010). However, it contradicts the works of others (Donkoh \& Awuni, 2011a; Ansah et al., 2015; Habwe \& Walingo, 2008) who found that education either significantly reduces farmers' adoption of technologies or is unimportant in explaining technology adoption by farmers. Other studies have shown frequent contact with extension agents to enhance technology adoption among farmers (Abunga et al., 2012; Donkoh \& Awuni, 2011b). On the other hand, the positive effect of extension contact on technology adoption has been disputed by Abdallah et al. (2014) and Ansah et al. (2015), who established that extension visit is inversely related to the adoption of soil and water conservation technologies among farmers. The positive effect of access to credit on the 
adoption of technology is supported by others (World Vegetable Centre, 2006), who observed that farmers with improved income and access to credit are better users of improved technologies. These farmers can take more financial risks than lowincome farmers. Farmers experiencing high levels of poverty and those who lack access to credit find it difficult to afford modern technologies in agricultural production (Faber et al., 2010). As the size of the farm increases, the level of technology adoption also increases because large scale farmers are more commercially oriented and hence are more likely to adopt technologies that increase yield. The negative effect of a farmer's years of experience on the tendency to adopt technology was expected. It was hypothesised that the more a farmer engages in vegetable production, the greater the know-how in production in the long run. Hence, farmers' probability of relying on their past production experience is high, with a lower likelihood of adopting new technologies. Also, younger farmers have less farming experience but are more commercially oriented and will have a higher probability of adopting new technologies than the older and more experienced farmers.

\section{Conclusion}

It is evident that the cultivation of traditional leafy vegetables is and will continue to be part of the farming system in northern Ghana as the consumption of traditional vegetables is rooted in the culture of the people. Traditionally, leafy vegetables constitute an important component of local diets and, as a result, contribute to household food security. However, the commercialisation of traditional African vegetables has not achieved much success due to farmers' inadequate access to, and poor technology adoption. This limits the contribution of traditional leafy vegetables to household income security. While researchers have accorded traditional African vegetables little attention, agricultural extension support is generally skewed toward other crops. This is against the backdrop that most farmers are willing to adopt improved technology to improve household incomes from the cultivation of vegetables. Thus, traditional African vegetables are neglected mainly and their cultivation based largely on farmers' traditional knowledge and practices. Farmers' educational level, access to credit, farm size, farmers' experience, labour and access to extension support are important factors to consider in promoting improved technologies among traditional vegetable farmers in northern Ghana. Unfortunately, farmerextension contact and access to credit are rather low as only a few traditional vegetable farmers have access to extension contacts and credit.

\section{Recommendation}

Traditional vegetables have the potential to contribute significantly to household food security and incomes among rural households. However, several challenges must be addressed to make this a reality. Some recommendations are therefore made in this regard:

There is a need for policy re-orientation of the agricultural extension system to allow for more attention to less favoured crops like traditional African vegetables. This study underscores the need for an improved extension on traditional African vegetables. It is demonstrated amply by the lack of awareness and adoption of improved vegetable cultivation technologies among farmers. In addition, access to extension by farmers outside formal irrigation schemes needs to increase.

Research is a key driver of the sustainability of agricultural systems, just as it is for any other system. However, the study revealed that farmers have little or no access to post-harvest technology and improved varieties. The absence of research on traditional African vegetables generally is explained by the fact that they are not considered major crops as far as food security is concerned. Consequently, there is a need to re-think agricultural research, especially on traditional African vegetables, as there is ample evidence to prove that they contribute to household food security via improved nutrition and income. 


\section{Acknowledgement}

This study was supported in part by a commissioned project granted to The World Vegetable Center by CORAF/WECARD no. $\mathrm{CW} / \mathrm{CP} / 03 / \mathrm{PCN} / \mathrm{NSC} / 02 / 2012$

(grant AVRDC 10000224) and funded through the World Bank by a Multi-Donor Trust Fund composed of the European Union and the Canadian International Development Agency.

\section{References}

Abdallah, A-H., Ayamga, M. \& Donkor, S.A. (2014). Smallholder adoption of soil and water conservation techniques in Ghana. African Journal of Agricultural Research, 9(5), 539546. https://doi.org/10.5897/ajar2013.7952

Abukutsa-Onyango, M.O. (2010). African indigenous vegetables: strategic repositioning in the horticulture sector. Second inaugural lecture of Jomo Kenyatta University of Agriculture and Technology (JKUAT), Nairobi, Kenya.

Abunga, M., Emelia, A., Samuel, G. \& Dadzie, K. (2012). Adoption of modern agricultural production technologies by farm households in Ghana: What factors influence their decisions? Journal of Biology, Agriculture and Healthcare. Vol (2)3, 1-14.

Adebooye, O. C. \& Opabode, J. T. (2004). Status of conservation of the indigenous leafy vegetables and fruits of Africa. African Journal of Biotechnology, 3(12), 700-705.

Afari-Sefa, V., Tenkouano, A., Ojiewo, C. O., Keatinge, J. D. H. \& d'A. Hughes, J. (2012). Vegetable breeding in Africa: constraints, complexity and contributions toward achieving food and nutritional security. Food Security, 4(1), 115-127. https://doi.org/10.1007/s12571011-0158-8

Agency for Health and Food Security(2020). Strengthening agricultural value chain economics for sustainable development (SAVES): a focus on vegetables. Final research report..

https://ahefs.org/documents/SRF20.pdf.

downloaded on 12/23/2020.

Amoah, S.T., Debrah, I. A. \& Abubakari, R. (2014). Technical efficiency of vegetable farmers in peri-urban Ghana influence and effects of resource inequalities. American Journal of Agriculture and Forestry, 2 (3):79-87. doi: 10.11648/j.ajaf.20140203.14.

Ansah I.G.K, Damasius, E. \& Amoako, R. (2015). Socio-economic determinants of livestock production technology adoption in Northern Ghana. Asian Journal of Agricultural Extension, Economics and Sociology 5(3),166182

Amfo, B. \& Ali, E.B. (2020). Technology adoption by indigenous and exotic vegetable farmers. International Journal of Vegetable Science. DOI: 10.1080/19315260.2020.1724228

Chagomoka T, Drescher A, Glaser R, Marschner B, Schlesinger J. \& Nyandoro, G. (2015). Vegetable production, consumption and its contribution to diets along the urban - rural continuum in northern Ghana. African Journal of Food, Agriculture, Nutrition and Development, 15(4), 10352-103567

Chagomoka, T., Afari-sefa, V. \& Pitoro, R. (2013). Value chain analysis of indigenous vegetables from Malawi and Mozambique. 4th International Conference of the African Association of Agricultural Economists, 1-44. http://purl.umn.edu/161449

Donkoh, S. A \& Awuni, J. A. (2011a). Farmers , perceptions and adoption of improved farming techniques in low-land rice production in Northern Ghana. Fourth Tokyo International Conference for African Development (TICAD IV. 1-16).

Donkoh, S. A. \& Awuni, J. A. (2011b). Adoption of farm management practices in lowland rice production in Northern Ghana. Journal of Agricultural and Biological Science, 2(4), 8493.

Donkoh, S. A., Azumah, S.B. \& Awuni, J. A. (2019). Adoption of improved agricultural technologies 
among rice farmers in Ghana: A multivariate probit approach. Ghana Journal of Development Studies, Vol. $16 \quad$ (1) DOI//http://dx.doi.org/10.4314/gjds.v16i1.3

Etwire, P. M., Al-Hassan, R. M., Kuwornu, J.K.M. \& Osei-Owusu, Y. (2013). Smallholder farmers' adoption of technologies for adaptation to climate change in Northern Ghana. Journal of Agricultural Extension and Rural Development, 5(6), 121-129. DOI: 10.5897/JAERD13.0481 ISSN 2141-2170 @2013 Academic Journals http://www.academicjournals.org/JAERD

Faber, M., Oelofse, A., van Jaarsveld, P. J., Wenhold, F. A. M. \& Van Rensburg, J. W. S. (2010). African leafy vegetables consumed by households in the Limpopo and KwaZuluNatal provinces in South Africa. South African Journal of Clinical Nutrition, 23(1), 30-38. https://doi.org/10.1080/16070658.2010.11734 255

Ghana Statistical Service (2010). Population and Housing Census. Summary Report, Final, 2010. https://statsghana.gov.gh/gssmain/fileUpload/p ressrelease/2010_ $\quad \mathrm{PHC}_{\text {_ }} \quad$ National_ AnalyticalReport.pdf

Habwe, F. O., Walingo, K.M. and Onyango, M.A. (2008). Food processing and preparation technologies for sustainable utilisation of African indigenous vegetables for nutrition security and wealth creation in Kenya. In G.L., Robertson \& J.R., Lupien, (Eds). Using food science and technology to improve nutrition and promote national development. International Union of Food Science \& Technology (2008)

Issaka, Y. B., Antwi, M. \& Tawia, G. (2016). A comparative analysis of productivity among organic and non-organic farms in the West Mamprusi District of Ghana. Agriculture, 6(2), $1-10$.

https://doi.org/10.3390/agriculture6020013

Issaka, Y. B., Seidu, J. \& Tenkouano, A. (2016). Characterisation of rain-fed maise-based vegetable production systems in Northern Ghana. Scientific Research and Essays, 11(6),
64-75.

Kamga, R. T., Kouamé, C., Atangana, A. R., Chagomoka, T. \& Ndango, R. (2013). Nutritional evaluation of five African indigenous vegetables. Journal of Horticultural Research, 21(1), 99-106. https://doi.org/10.2478/johr-2013-0014

Kiambi, D. K. \& Atta-Krah, K. (2003). Plant genetic resources in the global and African setting. Proceedings of the First Plant Resources of Tropical Africa (PROTA) International Workshop. Nairobi, Kenya.

Kwarteng, A. T., Aidoo, R. \& Sarfo-Mensah, P. (2019). Determinants of the extent of adoption of maise production technologies in Northern Ghana. African Journal of Agricultural Research, 14(19), 819-827.

Mnzava, N. A. (1997). Vegetable crop diversification and the place of traditional species. In: L.Guarino (ed.), Traditional African vegetables: Promoting the conservation and use of Underutilised and neglected crops. 16th Proceedings of the IPGRI International Workshop on Genetic Resources of Traditional Vegetables in Africa: Conservation and use.Nairobi, Kenya. 1-15

Mohammed, G., Adam, H. \& Duniya, K. (2019). Factors influencing improved maise farming technologies adoption in Yendi Municipality of Northern Region of Ghana. International Journal of Irrigation and Agricultural Development, 3(1), 201-210.

https://www.ijirad.org/index.php/IJIRAD/articl e/view/58

Muhanji, G., Roothaert, R. L., Webo, C. \& Stanley, M. (2011). African indigenous vegetable enterprises and market access for small-scale farmers in East Africa. International Journal of Agricultural Sustainability, 9, 194-202. https://doi.org/10.3763/ijas.2010.0561

Muyonga, J. H., Nansereko, S., Steenkamp, I., Manley, M. \& Okoth, J. K. (2017). Traditional African foods and their potential to contribute to health and nutrition: Traditional African 
foods. In Shekhar, H. U., Howlader, Z. H., \& Kabir, Y. (Eds.), Exploring the nutrition and health benefits of functional foods (pp. 320346). IGI Global. http://doi:10.4018/978-15225-0591-4.ch015

Nchanji, E. B., Bellwood-Howard, I., Schareika, N., Chagomoka, T., Schlesinger, J., Axel, D. \& Rüdiger, G. (2017). Assessing the sustainability of vegetable production practices in northern Ghana, International Journal of Agricultural Sustainability, 15(3), 321-

337, DOI: $10.1080 / 14735903.2017 .1312796$

Ngugi, I. K., Gitau, R. \& Nyoro, J. K. (2006). Access to high-value markets by smallholder farmers of African indigenous vegetables. Regoverning Markets Innovative Practice Series, IIED, London.

Owusu V, Asante A. V. \& Pavelic P. (2013). Assessing the factors influencing groundwater irrigation technology adoption in Ghana. In M.H., Ali (ed.), Irrigation Management, Technologies and Environmental Impact (pp.181-192). Nova Science. Hauppauge. USA.

Plant Resources of Tropical Africa (2004). in: G.J.H. Grubben and O.A. Denton (eds), Vegetables (p.668). Backhuys Publishers. Leiden, The Netherlands:

Sinnadurai, S. (1973). Vegetable production in Ghana. Acta Horticulture, 33, 25-28 DOI:10.17660/ActaHortic.1973.33.3 https://doi.org/10.17660/ActaHortic.1973.33.3

Tenkouano, A. (2011). The nutritional and economic potential of vegetables. In Worldwatch Institute (ed.), State of the world's food and agriculture: Innovations that nourish the planet (pp. 27-38). W. W. Norton \& Company, New York

Uusiku, N.P., Oelofse, A., Duodu, K.G., Bester, M.J. $\&$ Faber, M. (2010). Nutritional value of leafy vegetables of sub-Saharan Africa and their potential contribution to human health: A review. Journal of Food Composition and Analysis, 23, 499-509. 10.1016/j.jfca.2010.05.002.

van Asselt, J., Masias, I. \& Kolavalli, S. (2018). Competitiveness of the Ghanaian vegetable sector: Findings from a farmer survey. GSSP Working Paper 47. International Food Policy Research Institute (IFPRI), Washington, DC. http://ebrary.ifpri.org/cdm/ref/collection/p157 38 coll2/id/132365

Vorster, H.J., Jansen van Rensburg, W.S., Venter, S.L. \& van Zijl, J.J.B. (2007). The importance of traditional leafy vegetables in South Africa. African Journal of Food, Agriculture, Nutrition and Development, 7 (4), 1-13

World Vegetable Centre (2006). Empowering small scale and women farmers through sustainable production, seed supply and marketing of African indigenous vegetables in Eastern Africa. Final Report (1 February 2004-31 January 2006). AVRDC - The World Vegetable Center and Family Concern, Taiwan.

Zakaria, A., Alhassan, S.I. \& Kuwornu, J.K.M. (2020). Factors influencing the adoption of climate-smart agricultural technologies among rice farmers in Northern Ghana. Earth Systems Environment, (4), 257-271. https://doi.org/10.1007/s41748-020-00146-w 